CIVICS EDUCATION AND SOCIAL SCIENSE JOURNAL(CESSJ)

Volume 2 Nomor 2 Edisi Bulan Desember 2020

\title{
KEGIATAN BELAJAR BERSAMA ANGKRING SINAU SEBAGAI SOLUSI PENGONDISIAN BELAJAR AKTIF DAN KREATIF DI TENGAH PANDEMI COVID-19
}

\author{
Penulis \\ Sugeng Santoso \\ Universitas Pendidikan Ganesha \\ sugengsantoso73700@gmail.com
}

\begin{abstract}
ABSTRAK
Penelitian ini bertujuan untuk mendeskripsikan pelaksanaan Angkring Sinau yang dilaksanakan di RT 1 RW 2 Desa Jatilengger, Kecamatan Ponggok, Kabupaten Blitar, sebagai solusi pengondisian belajar aktif dan kreatid di tengah pandemi COVID19. Angkring Sinau adalah kegiatan belajar bersama untuk siswa usia TK s/d SMP dengan melibatkan sukarelawan pengajar.Penelitian ini berjenis penelitian kualitatif dengan pendekatan deskriptif. Subjek yang diteliti adalah pengondisian belajar aktif dan kreatif di tengah pandemi COVID-19, sedangkan objeknya adalah kegiatan belajar bersama Angkring Sinau.

Teknik pengumpulan data yang digunakan adalah observasi dan kuisioner. Setelah data terkumpul lalu akan dioleh dengan teknik Miles dan Huberman, yang meliputi beberapa tahap; reduksi data, penyajian data, dan penarikan kesimpulan. Penelitian ini medapatkan hasil bahwa persiapan dan pelaksanaan Angkring Sinau terdiri dari lima tahap. Tahap-tahap tersebut adalah persiapan, perizinan, penyosialisasian, pelaksanaan, dan evaluasi. Tanggapan dari siswa dan orang tua pun juga baik. Harapan dibentuknya kegiatan Angkring Sinau adalah dapat menciptakan ruang belajar yang aktif dan kreatif untuk siswa, sehingga dapat membantu meningkatkan hasil belajar dari segi kuantitas dan kualitas.
\end{abstract}

Kata kunci : Angkring Sinau, belajar, COVID-19. 


\title{
LEARNING ACTIVITIES WITH ANGKRING SINAU AS A SOLUTION FOR ACTIVE AND CREATIVE LEARNING CONDITIONS IN THE MIDDLE OF THE COVID-19 PANDEMIC
}

\author{
Author \\ Sugeng Santoso \\ Ganesha University of Education \\ sugengsantoso73700@gmail.com
}

\begin{abstract}
This research aims to describe the implementation of Angkring Sinau which be held in RT 1 RW 2 Jatilengger Village, Ponggok, Blitar, as a conditioning solution for active and creative learning in the midst of the COVID19. Angkring Sinau is a group learning activity for kindergarten into junior high school students involving volunteer as teaching staff. This research is a qualitative research with a descriptive approach.

The subjects of this research is active and creative learning conditioning in the midst of the COVID-19, while the object was learning activities in Angkring Sinau. The data collection techniques used were observation and questionnaires. After the data is collected, it will be obtained using the Miles and Huberman technique, which includes several stages; data reduction, data presentation, and making conclusions. This research found that the preparation and implementation of Angkring Sinau consists of five stages. These stages are preparation, licensing, socialization, implementation, and evaluation. The response from students and parents was also good. The hope of establishing the Angkring Sinau activity is that it can create active and creative learning place for students, so that it can help improve learning result in terms of quantity and quality.
\end{abstract}

Keywords: Angkring Sinau, COVID-19, learning.

JORNAL PROGDI PPKn, FKIP UNIVET BANTARA SUKOHARJO BEKERJA SAMA DENGANASSOSIASI PROFESI PENDIDIKAN PANCASILA DAN KEWARGANEGARAAN (AP3KNI) JAWA TENGAH 
CIVICS EDUCATION AND SOCIAL SCIENSE JOURNAL(CESSJ)

Volume 2 Nomor 2 Edisi Bulan Desember 2020

\section{PENDAHULUAN}

Saat ini dunia sedang digegerkan dengan sebuah virusyang dapat menginfeksi manusia. Virus tersebut bernama COVID-19 (SARS-CoV2). Virus COVID-19 muncul pada akhir tahun 2019 diKota Wuhan, China. Dikutip dari pernyataan Dong (dalam Putri, 2020), WHO telah memasukan COVID-19 darurat kesehatan masyarakat yang menjadi perhatian dunia. WHO menetapkan hal tersebut pada 30 Januari 2020. Pusat Pengendalian dan Pencegahan Penyakit Amerika Serikat (dalam Pranita, 2020) menyebutkan delapan gejala pasien COVID-19 di antaranya, demam tinggi, batuk dan pilek, berkurangnya fungsi penciuman dan panca indera, berkurangnya fungsi indera pengecap, sesak napas, sakit tenggorokan, dan mata merah. Virus COVID-19 mulanya masuk ke Indonesia pada awal Maret 2020. Saat itu hanya 1 (satu) kasus saja yang terdeteksi. Hingga akhirnya kasus tersebut terus berkembang dan merambah hingga saat ini. Berdasarkan data statistik Satuan Tugas (Satgas) Penganan COVID-19 Indonesia, per tanggal 26 Oktober 2020, kasus COVID-19 menginjak 392.934 kasus terkonfirmasi. Jumlah kasus yang masih aktif adalah 61.851 kasus. Total pasien sembuh adalah 317.672 orang. Serta, total pasien meninggal adalah 13.411 orang.

Merebaknya kasus COVID-19 di Indonesia telah memporak-porandakan berbagai sektor. Mulai dari ekonomi, pendidikan, kesehatan, dan banyak sektor lagi. Dalam bidang pendidikan, virus COVID-19 telah menyebabkan perubahan pada sistem pembelajaran. Pembelajaran yang sebelumnya menggunakan metode tatap muka kini harus beralih pada metode virtual (maya). Karena keadaan yang tiba-tiba, pembelajaran daring di Indonesia pun tidak lepas dari beragam kendala. Menurut Aji (2020), beberapa kendala belajar daring yang saat ini dihadapi oleh Indonesia di antaranya, (1) keterbatasan penguasaan teknologi dan informasi oleh pihak guru dan siswa; (2) sarana dan prasarana kurang memadahi; (3) akses internet yang terbatas dan belum merata; serta, (4) kurang siapnya penyediaan anggaran.

Selain kendala yang sudah disebutkan, masih terdapat kendala lain yang berasal dari siswa. Misalnya kurangnya motivasi, stagnannya cara belajar, dan tidak adanya guru yang menjelaskan secara langsung. Walaupun sudah banyak orang tua yang memasukkan siswa dalam program bimbingan belajar (bimbel), namun tidak semua siswa dapat merasakannya. Terlebih lagi, orang tua yang memilih mengajar anaknya sendiri dapat memicu stres dan kemarahan. Menurut Gusniar (2020), orang tua yang mengajari anak dengan teriakan dan perasaan marah akan membuat anak tertekan dan akan menganggu perkembangan mentalnya.

Untuk mengatasi permasalahan di atas, maka solusi yang bisa dilakukan adalah membentuk kelompok belajar bersama. Salah satunya kegiatan belajar bersama Angkring Sinau. Angkring Sinauadalah kegiatan belajar bersama dengan melibatkan sukarelawan dan siswa di sekitar tempat tinggalnya. Angkring (pos 
ronda) dipilih karena keberadaannya yang sedang marak di daerah Kabupaten Blitar. Masyarakat Kabupaten Blitar kembali melakukan jaga malam sebagai respons dari kebijakan Menteri Hukum dan HAM, terkait pembebasan ribuan napi dalam program asimilasi dan integrasi, yang membuat warga menjadi dan waswas dalam hal keamanan.

\section{KAJIAN TEORI}

\section{Pembelajaran Daring di Tengah Pandemi COVID-19}

Pembelajaran daring adalah pembelajaran yang dilaksanakan secara tidak langsung menggunakan media teknologi digital. Pembelajaran dari diterapkan oleh pemerintah utuk meminimalisasi persebaran virus COVID19. Pembelajaran daring di Indonesia sendiri diberlakukan per tanggal 16 Maret 2020.

Karena diterapkan tanpa persiapan yang matang, pembelajaran daring di tengah pandemi tidak berjalan dengan lancar. Anugraha (2020) menyebutkan, beberapa hambatan pembelajaran daring bagi guru di antaranya; sulitnya mencari jaringan internet,tidak semua siswa memiliki ponsel, siswa mudah bosan dengan media yang diberikan. Sedangkan hambatan bagi siswa di antaranya; siswa lebih paham jika dijelaskan langsung oleh guru, orang tua siswa tidak bisa mengajari siswa.

Harnani (2020) mengungkapkan, pembelajaran daring yang dilaksanakan pada masa pandemi COVID-19 tidak seefektif kegiatan pembelajaran tatap muka (konvensional). Hal itu terjadi karena terdapat beberapa materi harus dijelaskan tanpa perantara dan lebih rinci. Di sisi lain, materi yang sudah disampaikan oleh guru secara daring juga belum tentu dapat dipahami seluruh siswa.

\section{Pembelajaran Aktif dan Kreatif}

Pembelajaran aktif adalah salah satu strategi pembelajaran yang melibatkan keaktifan siswa di dalamnya. Menurut Nofrinda (2019), belajar aktif haruslah lincah, penuh semangat, penuh akan gairah, dan menyenangkan untuk siswa. Kegiatan belajar aktif tidak dapat dilepaskan dari peran guru dalam menyusun strategi yang efektif dan efisien untuk pembelajaran, sehingga pembelajaran dapat memberikan makna bagi siswa, serta tujuan pembelajaran yang dicanangkan pun tercapai.

Menurut Pentury (2017), pembelajaran kreatif mengharuskan pendidik (guru) untuk dapat merangsang danmemunculkan daya kreatifitas siswa. Kreatifitas yag dimaksud adalahdalam konteks paradigmaatau pun dalam konteks kreatif bertindak. Kreatif dalam berparadigmaadalah kemampuan yang imajinatif namun bersifat rasional. 


\section{METODE}

Penelitian ini menggunakan pendekatan penelitian kualitatif. Penelitian kualitatif ditujukan untuk memahami fenomena-fenomena sosial dari sudut atau perspektif pastisipan (Siyoto dan Sodik, 2015). Partisipan yang dimaksud adalah orang yang diwawancarai, diminta memberikan data, pemikiran, atau pendapat.

Jenis penelitian yang digunakan dalam penelitian ini adalah penelitian deskriptif. Penelitian deskriptif merupakan penelitian yang paling sederhana dibanding penelitian-penelitian lain, karena penelitian ini tidak melakukan apaapa pada obyek yang diteliti. Penelitian deskriptif hanya akan mendeskripsikan fenomena yang ada di lapangan.

\section{Subjek dan Obyek Penelitian}

Subjek penelitian ini adalah pengondisian pembelajar aktif dan kreatif. Sedangkan objek penelitiannya adalah kegiatan belajar bersama Angkring Sinauyang dilaksanakan di angkring RT 1 RW 2 Desa Jatilengger, Kecamatan Ponggok, Kabupaten Blitar.

\section{Metode Pengumpulan Data}

Untuk mendapatkan data yang akan diolah dalam penelitian, maka diperlukan metode untuk mengumpulkan data. Adapun metode pengumpulam data yang digunakan adalah metode observasi dan metode kuisioner. Metode observasi digunakan untuk melihat dan mengamati proses kegiatan Angkring Sinau berlangsung. Sedangkan metode kuisioner dilakukan untuk mendapatkan data berupa jawaban (pendapat) dari para informan (siswa dan orang tua). Pengumpulan data kuisioner dilakukan dengan cara yang konvensional. Hal tersebut dilakukan karena masih minimnya pemahaman teknologi oleh responden.

\section{Teknik Analisis Data}

Teknik analisis data yang akan digunakan untuk menganalisis data yang telah dikumpulkan adalah menggunakan model Miles dan Huberman. Dalam (Santoso, 2018) model ini meliputi tiga komponen, yaitu sebagai berikut.

1) Reduksi Data

Kegiatan yang dilakukan dalam reduksi data adalah memilih hal-hal pokok yang sesuai dengan fokus penelitian. Reduksi dilakukan dengan membuang bagian-bagian yang tidak diperlukan.

2) Sajian Data

Setelah data direduksi, maka kegiatan selanjutnya penyajian data, yaitu upaya untuk menampilkan sekumpulan informasi yang sudah disusun 
secara sistematis sehingga memungkinkan peneliti untuk menarik simpulan atau suatu tindakan.

3) Penarikan Simpulan

Dalam penelitian ini, peneliti merumuskan simpulan berdasarkan data yang diperoleh dan menyajikannya secara deskriptif kualitatif, yaitu menyajikan temuan di lapangan dengan kata-kata.

\section{HASIL PENELITIAN DAN PEMBAHASAN}

\section{Angkring Sinau}

Angkring Sinau adalah kegiatan belajar bersama dengan melibatkan sukarelawan dan siswa di sekitar tempat tinggal sukarelawan tersebut. Angkring adalah pos ronda yang digunakan dalam berjaga malam. Penyebutan angkring berbeda-beda pada tiap-tiap daerah. Ada yang menyebutkan angkring, pos ronda, pos, gerdu, posko, dan masih banyak lagi. Sinau artinya belajar. Sinau berasal dari bahasa Jawa. Jika digabungkan, maka Angkring Sinau memiliki arti pos untuk belajar.

Angkring dipilih sebagai tempat pelaksanaan belajar bersama karena tempatnya yang terbuka dan fasilitas yang cukup. Pada masa pandemi COVID-19 banyak angkring yang sudah dilengkapi dengan sinyal wi-fi, lubang listrik, bahkan tv. Umumnya angkring tidak terpakai pada pagi dan siang hari, karena kegiatan jaga hanya dilakukan saat malam.

Kegiatan Angkring Sinauyang dilaksanakan di angkring RT 1 RW 2 Desa Jatilengger, Kecamatan Ponggok, Kabupaten Blitar, diikuti oleh sebanyak 14 siswa, dari jenjang TK hingga SMP. Jumlah sukarelawan pengajar adalah 2 orang yang berasal dari kalangan mahasiswa. Pembelajaran di Angkring Sinaudilakukan dalam tiap kloter. Kloter pertama adalah pukul 08.00 s/d pukul 09.00 untuk siswa SD dan TK, sedangkan kloter kedua adalah pukul $09.00 \mathrm{~s} / \mathrm{d}$ pukul 10.00 yang diperuntukkan untuk siswa SMP.

Tabel 1.

Jumlah Siswa Kegiatan Angkring Sinau

\begin{tabular}{|c|c|}
\hline \hline Jenjang & Jumlah \\
\hline TK & 2 \\
\hline SD & 5 \\
\hline SMP & 6 \\
\hline Total & 14 \\
\hline
\end{tabular}


Dalam pelaksanannya, pengajar serta pelajar Angkring Sinauharus menaati protokol kesehatan yang ditetapkan oleh pemerintah. Seperti memakai masker, berjaga jarak, mencuci tangan, dan tidak datang belajar ketika merasa kurang sehat.

Strategi pembelajaran yang digunakan dalam kegiatan Angkring Sinauadalah mengunakan strategi siswa belajar aktif. Pembelajaran siswa aktif dilakukan dengan cara merangsang daya pikir siswa dengan sumber materi yang dipelajari pada hari itu. Siswa akan diminta mencoba mempelajari dan mengeksplor materi yang ada, dan dilanjutkandengan ulasan kembali dan konfirmasi oleh sukarelawanpengajar. Untuk mempertebal pemahaman, dalam pengulasan materi kembali juga akan divisualisasikan hal-hal yang ada dalam kehidupan sehari-hari.

Untuk membuat atmosfer pembelajaran menjadi kreatif dan menyenangkan, maka siswa diberikan kebebasan dalam membuat model tata letak penulisan tugas di buku masing-masing. Selain itu siswa juga dipersilakan menggunakan fasilitas teknologi yang ada di angkring tempat belajar. Fasilitas tersebut adalah sinyal wi-fi gratis dan juga ponsel milik sukarelawan, bagi siswa yang tidak memiliki ponsel.

Pengembangan bakat siswa dalam kegiatan Angkring Sinau dilakukan dengan kegiatan ekstrakurikuler. Ekstrakurikuler terdiri dari menggambar, menulis puisi, mendongeng, dan english singing. Pemilihan beberapa ektrakurikuler tersebut didasari atas tujuan tertentu. Seperti melanggengkan budaya Jawa melalui dongeng, dan memperhalus perasaan siswa melalui puisi dan menggambar. Sedangkan ekstrakurikuler english singingbertujuan untuk mengajak siswa belajar bahasa internasional dengan cara yang lebih menyenangkan.

Per tanggal 1 November 2020, ekstrakurikuler Angkring Sinau sudah mengeluarkan beberapa siswa untuk menjadi delegasi dalam perlombangan nasional. Rinciannya adalah 3 siswa pada lomba cipta puisi nasional, 2 siswa dalam lomba menggambar nasional, dan 1 orang dalam lomba mendongeng nasional. Pelaksanaan ekstrakurikuler Angkring Sinaudilaksanakan secara fleksibel.

Gambar 1.

Pengajar dan Siswa Angkring Sinau

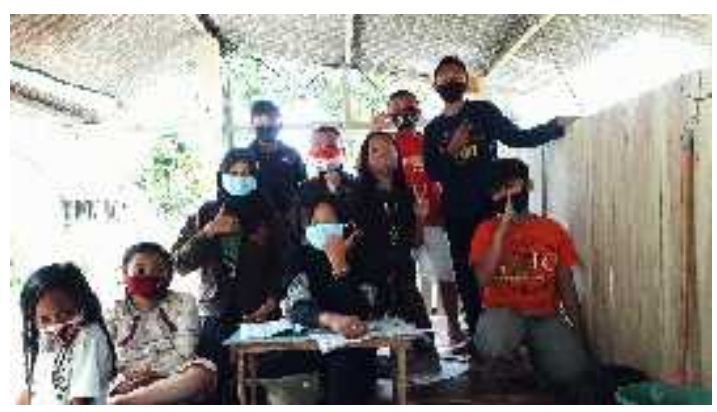

JORNAL PROGDI PPKn, FKIP UNIVET BANTARA SUKOHARJO BEKERJA SAMA DENGANASSOSIASI PROFESI PENDIDIKAN PANCASILA DAN KEWARGANEGARAAN (AP3KNI) JAWA TENGAH 
Persiapan dan pelaksanaan kegiatan Angkring Sinauterdiri atas beberapa tahapan. Tahapan tersebut harus disusun dan dilaksanakan dengan sistematis agar kegiatan dapat berjalan dengan lancar. Tahapan yang dimaksud dapat dilihat pada bagan berikut ini.

\section{Gambar 2.}

TahapanPerancangan Kegiatan Angkring Sinau

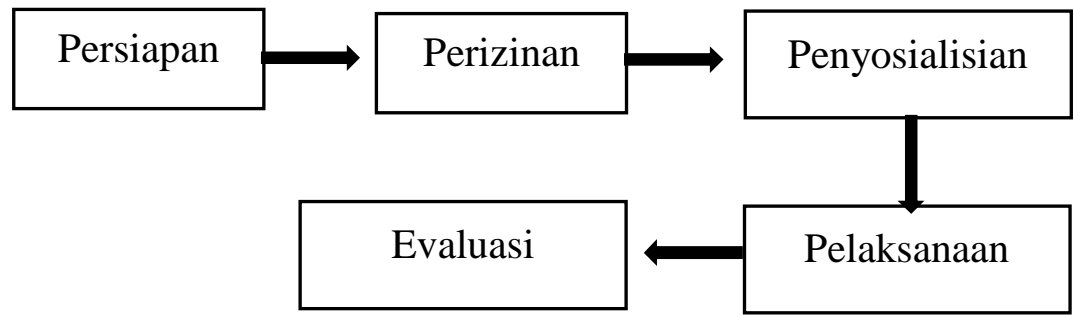

\section{Persiapan}

Tahap persiapan adalah tahap pemilihan/pembentukan sukarelawan. Sukarelawan dapat berasal dari siswa SMA, mahasiswa, atau masyarakat umum yang memiliki kemampuan dan kemauan mengajar. Dalam tiap angkring bisa diisi oleh satu atau dua orang pengajar, dengan rasio pengajar dengan siswa maksimal 1:4 per pertemuan. Selain menentukan sukarelawan, tahap persiapan juga berfungsi untuk merencanakan rentangan pelaksanaan kegiatan, atau pun merencanakan sistem pembelajaran nanti.

\section{Perizinan}

Tahap perizinan dilakukan dengan cara meminta izin kepada Ketua RT atau orang memiliki fasilitas dalam angkring perihal akan mengadakan pembelajaran bersama. Namun jika terdapat angkring yang terlalu kecil, maka disarankan untuk tidak dipakai. Sukarelawan bisa memilih tempat tinggal untuk melaksanakan kegiatan semacamAngkring Sinau.

\section{Penyosialisasian}

Tahap ini adalah tahap untuk mencari siswa dan/atau mengenalkan kegiatan pada warga sekitar yang memiliki anak usia sekolah. Metode untuk sosialisasi bermacam-macam. Sukarelawan dapat melakukan sosialisasi dengan cara mengirim pesan ke grup WhatsApp RT, mengirim pesan secara pribadi, hingga mendatangi rumah warga secara langsung. Agar tidak terjadi pembludakan peserta, maka harus dilaksanakan sistem registrasi.

\section{Pelaksanaan}

Tahap pelaksanaan adalah tahap eksekusi dari kegiatan Angkring Sinau. Pelaksanaan kegiatan bisa dilakukan dalam kurun waktu yang sudah 
ditentukan. Jika jumlah peserta masih belum memenuhi kuota yang ditetapkan, maka peserta boleh mendaftar pada saat kegiatan belajar sudah berlangsung.

\section{Evaluasi}

Tahap evaluasi dilaksanakan untuk mengoreksi kekurangan yang ada selama kegiatan berlangsung. Di samping mengoreksi kekurangan, tahap evaluasi dapat dilakukan untuk mencari hal positif yang sudah dilakukan, lalu selanjutnya akan dapat terus diterapkan atau ditingkatkan. Evaluasi bisa dilakukan selama satu minggu sekali, pada akhir pekan.

\section{Tanggapan Siswa dan Orang Tua Siswa terhadap Kegiatan Angkring Sinau}

Untuk mengetahui respons siswa dan orang tua siswa terhadap kegiatan Angkring Sinau, maka dilakukan penyebaran kuisioner. Pertanyaan kuisioner tersebut disusun berdasarkan beberapa aspek yang sudah dipertimbangan. Jumlah pertanyaan adalah 5 butir, dengan 3 pilihan jawaban. Pilihan jawaban tersebut meliputi "setuju", "biasa saja", dan "tidak setuju". Jumlah responden adalah 26 orang dengan rincian 12 orang tua dan 14 siswa. Komposisi antara orang tua dengan siswa tidak seimbang karena terdapat 2 orang tua yang mengikutkan 2 siswa dalam kegiatan Angkring Sinau.

Tabel 2.

Jumlah Responden

\begin{tabular}{|c|c|}
\hline \hline Jenis Responden & Jumlah \\
\hline Orang Tua & 12 \\
\hline Siswa & 14 \\
\hline Total & 26 \\
\hline
\end{tabular}

Berdasarkan kuisioner yang sudah disebarkan kepada orang tua siswa, hasil yang didapatkan adalah sebagai berikut. Pertama, keseluruhan responden orang tua menyatakan "setuju" bahwa keberadaan Angkring Sinau membantu bagi pembelajaran anak-anak. Kedua, keseluruhan responden orang tua juga menyatakan "setuju" bahwa dengan adanya Angkring Sinau, siswa menjadi lebih semangat dalam belajar. Ketiga, sebanyak 91,6\% responden orang tua siswa menyatakan "setuju" bahwa Angkring Sinau dapat membantu menyalurkan bakat anak-anak, sedangkan sebanyak 8,4\% menyatakan "biasa saja". Dalam pertanyaan keempat, semua orang tua siswamemilih jawaban "setuju" dalam hal keberlanjutan Angkring Sinau.Terakhir, semua reponden orang tua menyatakan bahwa kinerja sukarelawan Angkring Sinau memuaskan. 
Hasil kuisioner yang diberikan kepada siswa adalah sebagai berikut. Pertama, semua responden menyatakan "setuju" bahwa keberadaan Angkring Sinaudapat membantu pembelajaran. Kedua, semua responden menyatakan "setuju" bahwa keberadaan Angkring Sinaumembuat belajar menjadi lebih bersemangat. Ketiga, semua reponden memilih "setuju" bahwa keberadaan Angkring Sinaudapat membantu menyalurkan bakat. Keempat, semua responden juga memilih "setuju" jika kegiatan Angkring Sinauterus diadakan. Terakhir, semua responden menyatakan "setuju" bahwa kinerja sukarelawan Angkring Sinaumemuaskan.

\section{Harapan Dibentuknya Angkring Sinau}

Kegiatan belajar bersama Angkring Sinau diharapkan mampu mengurangi beban guru, siswa, dan orang tua dalam pembelajaran daring. Sehingga, siswa dapat belajar dengan baik meskipun tanpa hadirnya guru secara langsung. Selain itu, kegiatan ekstrkulikulerAngkring Sinaudiharapkan mampu membuat siswa dapat merasakan pendidikan yang bermutu, baik dari segi kualitas dan kuantitas. Kuantitas yang dimaksud adalah nilai mata pelajaran, sedangkan kualitas yang dimaksud adalah dari segi kualitas misalnya pendidikan karakter dan pewarisan nilai budaya yang luhur.

Sedangkan untuk masyarakat umum, kegiatan Angkring Sinaudiharapkan dapat menjadi contoh dan dorongan untuk masyarakat yang lain untuk turut menjadi sukarelawan di sekitar tempat tinggal masingmasing, dan dapat bersumbangsih dalam memajukan pendidikan di Indonesia. Mengingat saat ini pendidikan merupakan salah satu aspek penting yang terdampak oleh pandemi COVID-19.

\section{SIMPULAN}

Dari pembahasan di atas, maka dapat disimpulkan bahwa Angkring Sinau dapat menjadi solusi dalam pengondisian belajar aktif dan kreatif di tengah pandemi COVID-19. Hal tersebut sudah dibuktikan dengan meningkatnya semangat siswa dalam mengikuti kegiatan pembelajaran bersama. Selain itu, kesuksesan kegiatan Angkring Sinaujuga dapat dilihat dari tanggapan siswa, tanggapan orang tua, serta jumlah siswa yang bersedia menjadi perwakilan lomba nasional sesuai dengan ekstrakurikuler yang diikuti.

\section{REFERENSI}

Aji, Rizqon Halal Syah. 2020. Dampak Covid-19 pada Bidang Pendidikan di Indonesia: Sekolah, Keterampilan, dan Proses Belajar. Jurnal Sosial dan Budaya Syar-i FSH UIN Syarf Hidayatullah Jakarta, Vol. 7, No. 5, Tahun 2020. 
CIVICS EDUCATION AND SOCIAL SCIENSE JOURNAL(CESSJ)

Volume 2 Nomor 2 Edisi Bulan Desember 2020

Anugrahana, Andri. 2020. Hambatan, Solusi dan Harapan: Pembelajaran Daring

Gusniar, Gia. 2020. Orang Tua Murid, Orang yang Paling Stres dan Galak saat Pandemi. $\quad$ www.beritacianjur.com/orang-tua-murid-orang-yang-palingstres-dan-galak-saat-pandemi/. Diakses pada 2 November 2020, pukul 16.00 .

Harnani, Sri. 2020. Efektivitas Pembelajaran Daring di Tengah Pandemi Covid19.https://bdkjakarta.kemenag.go.id/berita/efektivitas-pembelajarandaring-di-masa-pandemi-covid-19. Diakses pada 28 Oktober 2020, pukul 14.00 .

Nofrinda, Rudi. 2019. Pembelajaran Aktif : Dimulai dari Guru Berakhir dengan Guruhttp://pena.belajar.kemdikbud.go.id/2019/12/pembelajaran-aktifdimulai-dari-guru-berakhir-dengan-guru/. Diakses pada 27 Oktober 2020, pukul 15.00.

Pentury, Helda Jolanda. 2017. Pengembangan Kreativitas Guru dalam Pembelajaran Kreatif Pelajaran Bahasa Inggris. Jurnal Ilmiah KependidikanFaktor, Vol. 4, No. 3, November 2017.

Pranita, Ellyon. 2020. Cemas Tertular Virus Corona, Berikut Gejala yang Harus Anda Curigai. www.kesehatan.kontan.co.id/news/cemas-tertular-viruscorona-berikut-gejala-yang-harus-anda-curigai. Diakses pada 26 Oktober 2020, pukul 15.20.

Putri, Ananda. 2020. Persebaran Virus COVID-19 di Indonesia. Jurnal Ilmu Kesehatan Masyarakat, Vol. 2, No. 1, Tahun 2020

Santoso, Sugeng, dkk. 2018. Penerapan Tri Hita Karana untuk Membentuk Karakter Siswa Taman Kanak-kanak dalam Menuju Indonesia Emas 2045. Paper. Singaraja: Universitas Pendidikan Ganesha.

Satuan Tugas (Satgas) Penganan COVID-19 Indonesia. 2020. Peta Persebaran. www.covid-19.go.id/peta-persebaran. Diakses pada 26 Oktober 2020, pukul 16.00.

Selama Masa Pandemi Covid-19 Oleh Guru Sekolah Dasar. Scholaria: Jurnal Pendidikan dan Kebudayaan, Vol. 10 No. 3, September 2020.

Siyoto, Sandu, dan Sodik, Ali 2015. Dasar Metodologi Penelitian. Sleman: Literasi Media Publishing.

JORNAL PROGDI PPKn, FKIP UNIVET BANTARA SUKOHARJO BEKERJA SAMA DENGANASSOSIASI PROFESI PENDIDIKAN PANCASILA DAN KEWARGANEGARAAN (AP3KNI) JAWA TENGAH 